Committee of the Research Council of Ontario; President of the Canadian Forestry Association of Ontario from 1947-51. Chairman of the Advisory Committee to the Minister of Lands and Forests of Ontario; Chairman of the Southern Ontario Section of the Canadian Institute of Forestry 1949-50 and Vice-President of the Canadian Institute of Forestry 1953-55.

Dean Sisam is the author of "The Use of Aerial Survey in Forestry and Agriculture, Joint Publication No. 9," Commonwealth Agricultural Bureaux, July, 1947. "The Establishment of Vegetation on Industrial Waste Land, Joint Publication No. 14," Commonwealth Agriculture Bureaux, 1949. And Dominion Forest Service Silvicultural Research notes and bulletins.

\title{
Secretary-Treasurer InCREases EXemptions
}

Dave Love, recently retired as Secretary-Treasurer of the C.I.F., added a second daughter, Nancy, to his family last May 7. His successor, J. D. Coats, proudly announces the arrival of Lynn Dianne.

\section{Entomologists MeET}

The 5th Annual Meeting of the Entomological Society of Canada and the Annual Meeting of the Acadian Entomological Society will be held at Fredericton, N.B., on October 18 to 20,1955 .

\section{Forest Fire Protection Course}

Courses in forest fire protection will be held again this year for the benefit of Ontario forest industry personnel, according to a recent announcement by Clark B. Davis, president of the Ontario Forest Industries Association.

The courses will be held as a co-operative effort by the 56-member company O.F.I.A. and the Ontario Dept. of Lands \& Forests, and will be given at two different locations - one in the western part of Ontario and one in the eastern section.

The western course will be held in the Great Lakes Paper Co. Ltd. depot camp at Martin, 125 miles west of Fort William, from July $11-14$ inclusive, while the other will be held at the Ontario Forest Ranger school, Dorset, from July 18-21 inclusive. Instructors are being provided without charge by some of the member companies and the Department.

Similar courses were held during 1953 and 1954, but this year will see the classes directed more to the training of foremen rather than the supervisory staffs. Those taking part in the courses will, in turn, pass on the information to other employees in the respective companies.

These courses, which are aimed at familiarizing woods personnel with fire prevention measures, include such training as: organizing fire crews; fighting fire with hand tools; investigation of fire causes; fighting fires with mechanical equipment; aerial fire fighting, and demonstrations of water-bombing and cargodropping techniques.

\section{S. A. F. Hold Annual Meeting}

The 55th Annual Meeting of the Society of American Foresters will be held in Portland, Oregon at the Multnomah Hotel on October 16 to 19, 1955. 